DOI: $10.17951 /$ lrp.2020.39.2.73-89

\title{
IZABELA SymonowiCZ-JABŁońsKa
}

Uniwersytet Mikołaja Kopernika

Wydział Filozofii i Nauk Społecznych

Instytut Nauk Pedagogicznych

Katedra Pedagogiki Szkolnej

ORCID - 0000-0003-2300-7988

\section{WYCHOWAWCZE IMPLIKACJE POSTACI CZAROWNICY - NIEZWYKŁEJ KOBIETY - W ŚWIETLE ZAŁOŻEŃ PEDAGOGIKI EMANCYPACYJNEJ}

\begin{abstract}
Streszczenie: Rozważania nad czarownicą-kobietą, wpisujące się w myśl założeń pedagogiki emancypacyjnej, mają ukazać modyfikację jej dotychczasowego wizerunku, otworzyć nową możliwość badawczą, która pozwoli na szersze spojrzenie na czarownicę - jako tłumaczkę kultury, niewpisującą się w główny, centralistyczny nurt myślenia o świecie. Zatem czy postać czarownicy-kobiety, widziana w podstawowych, stereotypowych konstrukcjach myślowych człowieka, jako postać destrukcyjna i złośliwa, która zawsze reprezentuje przeciwieństwo wszystkich pozytywnych wartości, może być postacią pozytywną? Czy „działa dwojako, będąc mitem, jest zarazem prawdą i złudzeniem” (Rella 2003, s. 295)? Czy obraz czarownicy zmienia się wraz z wiekiem dorastającego człowieka? Wartością dodaną artykułu są wyniki badań przeprowadzonych wśród młodzieży liceum ogólnokształcącego w Toruniu. Dzięki zastosowaniu badania wyjaśniającego powstał inwentarz cech definiujących czarownicę. Badaniem objęto 26 osób (13 z klasy o profilu humanistycznym i 13 z klasy o profilu matematyczno-informatycznym), aby określić różnice w zakresie werbalizowanych wartości między dwiema grupami profilowymi.
\end{abstract}

Słowa kluczowe: czarownica, pedagogika emancypacyjna, baśń/bajka

\section{WPROWADZENIE}

W refleksji pedagogicznej ważne miejsce zajmują rozważania nad znaczeniem bajek i baśni. Zazwyczaj są analizowane w ramach funkcji: edukacyjnej - w odniesieniu do sfery poznawczej - i moralnej (np. Redlarska 2015), terapeutycznej - sfery 
leczniczej (np. Molicka 1999) oraz ludycznej - sfery zabawy (np. Bolińska 2008), a także kreatywnej - sfery inspirowanej twórczością (Smogarzewska 2009). Maria Czerepaniak-Walczak zauważa natomiast, że najczęściej zupełnie pomijane są rozważania nad bajkami mogącymi zaburzać rozwój, zagrażać, bowiem nastawienie badawcze na ten ich aspekt nosiłoby „znamiona herezji” (Czerepaniak-Walczak 2003, s. 333). Dlatego też niniejszy tekst będzie skoncentrowany na określeniu znaczenia postaci baśniowej, często siejącej strach i grozę, jaką jest czarownica niezwykła kobieta, wpisująca się w nurt pedagogiki emancypacyjnej.

Rozważania będą oscylować wokół przyjętych założeń charakterystycznych dla pedagogiki emancypacyjnej, które opierają się m.in. na kształtowaniu emancypacyjnych kompetencji podmiotu w myśl proroczej ewokacji Czesława Miłosza: „Niech powstanie nowy człowiek, który nie ulega, ale przekształca świat i myśli w skali całego globu i sam stwarza formację historyczną, zamiast być jej niewolnikiem" (Miłosz 1953, s. 20). Według Hansa-Georga Gadamera pozwoli to zwrócić uwagę na fakt, że procedura rozumienia jest mediacją między przeszłością a współczesnością. Odnosząc się do tego stwierdzenia, istotne wydaje się wskazanie, że opowieść o jakimś działaniu zawiera zawsze teraźniejszość w kontekście przeszłości (Koczanowicz-Dehnel 2011, s. 33).

Warto podkreślić, że wartością dodaną artykułu jest inwentarz cech definiujących czarownicę, który powstał dzięki zastosowaniu badań wyjaśniających (Palka 2006, s. 130), szukających cech składających się na bycie czarownicą.

\section{KRÓTKA HISTORIA „CZAROWNIC”}

Bez zła nie rozumielibyśmy dobra, ale bez dobra i zła zarazem - nie zrozumielibyśmy istoty człowieczeństwa. Aby pojąć i uchwycić sens życia, nie wystarczy więc zbliżyć się ku doskonałemu, jakkolwiek wyobrażonemu Dobra, lecz także zrozumieć Zło (Rzepa 2003, s. 245).

Czarownica jest potrzebna zatem do tego, aby wyrazić całość ludzkiego doświadczenia. Narodziny jej mitu zbiegają się z momentem wynalezienia druku - jak zauważa Mona Chollet, wszystko zaczęło się od dzieła dwóch inkwizytorów: Alzatczyka Henricusa Institora (Heinricha Kramera) oraz pochodzącego z Bazylei Jakoba Sprengera, autorów książki Młot na czarownice (Chollet 2019, s. 13). Wywołała ona zbiorową panikę $w$ trakcie wielkich polowań na czarownice: „W tej epoce pożogi we wszystkich procesach dziełem tym posługiwali się sędziowie. Zadawali pytania zaczerpnięte $\mathrm{z}$ «Młota na czarownice» i wysłuchiwali 
zawartych w nim odpowiedzi" (Chollet 2019). Polskiemu czytelnikowi dzieło to przybliżył krakowski prawnik, Stanisław Ząbkowic, w 1614 roku. W tym czasie Polska powoli wchodziła w okres największych prześladowań czarownic w naszej historii, bowiem apogeum procesów przypada na lata 1670-1730. Było to wynikiem pogarszającej się sytuacji społeczno-politycznej i ogólnego upadku kultury w Rzeczypospolitej Obojga Narodów. Toczone w tym czasie wojny nie tylko przynosiły zniszczenia, epidemie, nieurodzaje, pomór bydła i głód, ale także niekorzystnie wpływały na ludzką psychikę. Nieszczęścia spadające na ludzi powodowały, że zaczynano szukać kozłów ofiarnych i chętniej ulegano złudzeniu, że za niepomyślne wypadki odpowiedzialne są siły nieczyste. Myślenie takie wzmacniała jeszcze kontrreformacja, która sprzyjała religijnemu fanatyzmowi ${ }^{1}$. „Miasta i całe regiony zmieniały swoją przynależność wyznaniową z dnia na dzień [...]. W obliczu takiej niepewności ludzie popadali w zbiorową histerię" (Cawihorne 2006, s. 7).

Pierwszą ofiarą polskich procesów czarownic była kobieta, którą spalono na stosie w Chwaliszewie w 1511 roku. Wówczas miasteczko to słynęło z warzelni piwa i gdy pewnego dnia mieszkańcy Poznania zatruli się przywiezionym stamtąd piwem, zaczęto szukać winnego. Za taką osobę uznano miejscową zielarkę. W kolejnych latach podobne przypadki zdarzały się coraz częściej. Oskarżano o czary głównie kobiety należące do klas ludowych. Jako istoty słabe na ciele i umyśle, skłonne do lubieżności i nienasyconej żądzy, uważano je za słabsze moralnie. Niektóre z oskarżonych miały kontakt z narodzinami i żywnością, z tajemnicą życia i śmierci (położne, kucharki). Nazywano je wiedźmami - starymi czarownicami, które znały lecznicze zioła i działanie różnych cudownych napojów.

W 1893 roku Matilda Joslyn Gage pisała: „Dysponujemy masą dowodów na to, że te rzekome «czarownice» należały do osób najgłębiej w owej dobie związanych z wiedzą". Według Jeana-Michela Sallmanna zbuntowana czarownica-kobieta dzięki znajomości medycyny i zjawisk przyrody stała się matką współczesnej nauki (Sallmann 1994, s. 126-127).

To kobieta, która leczy i pociesza. Jak czytamy u Julesa Micheleta:

To jej prawdziwe kapłaństwo. I do niej ono należy, cokolwiek powiedziałby o tym Kościół. Subtelność zmysłów, miłość i zrozumienie najdrobniejszych przejawów życia czyni kobietę wnikliwą znawczynią wszelkiej nauki opartej na obserwacji. Jej serce i litość, jej dobroć predestynuje ją na lekarkę. [...] Kobieta wkroczy więc w dziedzinę nauki i wniesie tam łagodność i ludzkość, jak uśmiech natury (Michelet 1961, s. 60).

\footnotetext{
${ }^{1}$ https://www.rp.pl/Rzecz-o-historii/310149995 [dostęp: 7.11.2019].
} 
Mimo ich pozytywnych cech kobiety obdarzone mniejszą siłą fizyczną, nieangażujące się w sprawy na arenie politycznej łatwiej było zepchnąć do roli kozła ofiarnego w życiu społecznym, do roli osób odpowiedzialnych za niepowodzenia innych ludzi. A przecież dopóki ich działalności nie powiązywano z diabelskim paktem, to do nich ludzie zwracali się o pomoc i zawsze były szanowanymi członkiniami społeczności. Co sprawiło, że zostały narażone na niebezpieczeństwo podejrzeń? Wystarczyła rozmowa podniesionym tonem $\mathrm{z}$ sąsiadem, silny charakter bądź nazbyt wyzwolona seksualność - każda niewygodna dla otoczenia postawa czy też znamię, nieregularna plamka na skórze, by przesądzić o losie kobiety (Chollet 2019, s. 16-17).

Zdaniem historyka Johna Demosa pierwszym motywem oskarżeń o czary wnoszonych przeciw kobietom w Nowej Anglii była ich zuchwałość wobec własnych małżonków (Chollet 2019, s. 172). Kobiety okrzyknięte czarownicami w oczach ich oprawców były nikczemne, stanowiły ucieleśnienie wszelkiego zła. Polowania na czarownice zazwyczaj były wymierzone w kobiety starsze, które wykazywały się pewnością siebie, czego mężczyźni nie mogli znieść. Były to bowiem czasy, gdy żądano okazywania uległości. Jak zaznacza autorka książki Czarownice. Niezwyciężona siła kobiet -

wszystkie kobiety, nawet te, których nigdy nie oskarżono, zaznały na własnym ciele skutków prześladowań i polowań na czarownice. Publiczny spektakl kaźni, stanowiący potężne narzędzie siania strachu i sprawowania zbiorowej dyscypliny, zmusił je do tego, by stały się bardziej łagodne, uległe, bezwolne, znalazły miejsce w cieniu i unikały rozgłosu (Chollet 2019, s. 22).

W pierwszej kolejności procesy rozpowszechniły się w rejonach, które miały największą styczność z kulturą niemiecką - Wielkopolsce i Prusach Królewskich; w późniejszym okresie, tj. pod koniec XVII wieku i na początku XVIII, nieszczęście to dotknęło Mazowsza. Najmniej procesów czarownic odbyło się w Małopolsce i na wschodnich ziemiach Rzeczypospolitej. Małgorzata Pilaszek twierdzi, że spośród 1316 oskarżonych życie straciło 558 osób (42\%). Częstotliwość zasądzania wyroków śmierci upodabnia więc Polskę do reszty Europy, gdzie na około 110 tys. procesów przypada około 60 tys. egzekucji (Pilaszek 2008).

Z powodu istnienia bogatego piśmiennictwa (np. Briggs 1998; Cawihorne 2006; Levack 2009; Stark 2018, s. 151-157) poświęconego istocie prześladowań kobiet poprzestanę na powyższych rozważaniach. Guy Bechtel przypomina, że „żadna grupa na świecie nie była nigdy tak długo obiektem obelg - jak kobiety” (Bechtel 2015). 


\section{PEDAGOGIKA EMANCYPACYJNA}

Ówczesna sytuacja polityczna - w dobie nowożytności - i panujący patriarchat sprawiły, że kobieta-czarownica stała się antagonistą panującej władzy. Dziś można ją postrzegać jako osobę eksponującą naczelny cel wychowania, umożliwiający bycie „wolną osobowością", wolną od przymusów, jakie niosą ze sobą państwo, religia, prawo i normy moralne (Śliwerski 2015, s. 286). Wówczas dążono do tego, aby pozbawić jednostkę możliwości samostanowienia, osiągnięcia własnej autonomii i „utrzymać ją w «karbach» zewnętrznych ograniczeń” (Śliwerski 2015, s. 287).

Kategoria czarownicy - kobiety zniewolonej, uciśnionej, niemogącej być taką, jaką chciałaby być - doskonale wpisuje się w założenia pedagogiki emancypacyjnej. W pedagogice emancypacyjnej bowiem istotą wychowania, nauczania jest wyzwolenie. „Wyzwolenie dotyczy ludzi, ich świadomości i związanej z nią sfery zachowań społecznych" (Kostyło 2019, s. 588). Wiąże się to ze zmianą przekonań dominujących we własnym życiu: uświadomienie sobie narzuconych ograniczeń oraz zakwestionowania ich, a także lepszego wykorzystania potencjału, który tkwi w jednostce. Narzędziem emancypacyjnym ma być edukacja. Zgodnie z myślą Marii Czerepaniak-Walczak, można stwierdzić, że „edukacja to tworzenie warunków samodzielnego osiągania dojrzałości poprzez osobiste poszukiwania stawiane w kontekście własnej sytuacji historycznej pytań o świat i jego elementy" (Czerepaniak-Walczak 2006, s. 12). W przypadku czarownicy mamy do czynienia z klasycznym przypadkiem stereotypu - konstrukcji opartej na niewiedzy i strachu. Z powodu swojej odmienności, a także wdrożenia przez środowisko komponentów myślenia stereotypowego zostaje ona kozłem ofiarnym (Girard 1991).

W przypadku czarownicy - kobiety zniewolonej - jej „duch inności”2 walczył o wyrażenie siebie, o kształtowanie osobowości, ale nie w postaci zewnątrzsterownej, przystosowanej do normatywnych, ideologicznych czy politycznych żądań panujących władz. Według Marii Czerepaniak-Walczak emancypacja jest „ideą podmiotowego uwalniania się od doświadczonych ograniczeń i samodzielnego zmieniania własnego położenia” (Czerepaniak-Walczak 2006, s. 7), jest „uwalnianiem się od stereotypów i opinii generujących opresywne relacje społeczne oraz usytuowanie osób i grup w strukturze społecznej, ekonomicznej, w kulturze i polityce” (Czerepaniak-Walczak 2006, s. 16), jest „procesem transgresji, wychodzenia poza to, co ustalone i uznane, upominania się podmiotu o prawo do bycia tym, kto zmienia siebie i świat" (Czerepaniak-Walczak 2006, s. 64).

\footnotetext{
${ }^{2}$ Określenie Marii Janion.
} 


\section{CZAROWNICA Z BAŚNI I BAJEK}

Doskonałym przykładem gotowości na zmiany, wolności słowa, stawania się wartościowym, niezależnym, odważnym i potrzebnym człowiekiem są bajki/baśnie - dawniej „prawdziwe historie”. Warto nadmienić, że do XVII wieku „bajka oznaczała coś wiarygodnego - ustne lub zapisane świadectwo mające moc prawną" (Propp 2000, s. 33). Później pod wpływem ustawy cara Aleksego jej znaczenie stało się sprzeczne i zaczęło funkcjonować w takim samym sensie jak dzisiaj (Propp 2000). Współcześnie baśń/bajka zatraciła charakter wiarygodności, ale wciąż można postawić ją na pograniczu dwóch światów: fikcyjnego i rzeczywistego. Zatem czy baśń/bajka jest dopełnieniem rzeczywistości, w której żyje czarownica, czy wyolbrzymieniem fikcji? Owo pogranicze z punktu widzenia edukacyjnego wydaje się tutaj znaczące.

Książka Mony Chollet Czarownice. Niezwyciężona siła kobiet uświadomiła mi, że czarownice z bajek mojego dzieciństwa (np. Baba Jaga, Jaś i Małgosia) nigdy nie były dla mnie postaciami okrutnymi, przerażającymi - takimi, których należy się bać, lecz kobietami tajemniczymi, magicznymi, dysponującymi mocą, przesyconymi mądrością i głębokim spokojem, który towarzyszył im w czasie przygotowywania zaklęć, eliksirów. Taki obraz czarownicy można dostrzec w powieści Dzieci Szklarza Marii Gripe:

Imię Furkota wzięło się stąd, że zawsze chodziła w szerokim, błękitnym płaszczu z zębatą pelerynką, która furkotała przy ramionach jak wielkie skrzydła. Na głowie nosiła bardzo dziwny kapelusz: nad jego ukwieconym rondem sterczała wysoka fioletowa główka ozdobiona motylami (Gripe 1983, s. 10).

Błękitne oczy, bijące blaskiem, „wydawały się łagodne, podobne do kwiatów, a przecież tchnęły grozą" (Gripe 1983, s. 12). Budząca postrach czarownica rozbudziła we mnie raczej ciekawość niż obojętność, bardziej ekscytację innym światem niż odrazę, prawdopodobniej otwierającą się przygodę niż nudę codziennego rytmu. Czarownica stała się postacią pozytywną, „to do niej należało ostatnie słowo, to ona pokazywała podłym ludziom, gdzie jest ich miejsce. Pozwalała zaznać rozkoszy zemsty na przeciwniku" (Chollet 2019, s. 9), który jej nie docenił. To kobieta pełna witalności, dysponująca mocą, którą trudno określić - wydaje się, że jest w niej jakaś siła wywołana bagażem jej doświadczeń.

Przykłady baśni z takim motywem, gdzie postać czarownicy zostaje zrehabilitowana, można by mnożyć (Symonowicz-Jabłońska 2018). Wówczas widzimy ją w zupełnie innych barwach: pomaga dorosnąć, reguluje stosunki między matką a córką, uczy samodzielności, odwagi w podejmowanych decyzjach, autonomii 
(Roszpunka); przygotowuje dziewczynkę do pełnienia roli kobiety: świadomej i odpowiedzialnej za swoje czyny. Czarownica obdarza zatem darem bycia kobietą (Śpiąca Królewna); dzięki czarownicy królewna odnajduje siłę, by się obudzić, uporać z trudnościami wieku młodzieńczego, dojrzeć i żyć pełnią życia; uczy kontroli nad sobą, odpowiedzialności za siebie i podejmowane wybory (Królewna Śnieżka); jest projekcją naszych życzeń i lęków, a kiedy się z nimi zmierzymy - odchodzi (Dwaj Bracia). W tym ostatnim utworze kończy swój żywot poprzez spalenie. Jej dwa oblicza ukazane z punktu widzenia pedagogiki emancypacyjnej wpływają na bohatera pozytywnie: uczłowieczają, wyzwalając z ograniczeń (np. brak swojego zdania), oraz dodają wiary w siebie. W Szewczyku Dratewce czarownica okazuje się niejako strażniczką - matką największego skarbu, jakim jest dziecko-dziewczynka-kobieta. Testuje każdego adoratora, aby wybrać dla niej najlepszego.

\section{BADANIA WŁASNE}

Badania przeprowadzono wśród młodzieży jednego z liceów ogólnokształcących $\mathrm{w}$ Toruniu. To na ich podstawie odtworzono wyobrażenie baśniowe, jakim jest czarownica w konceptualizacjach licealistów. Zastosowanie badania wyjaśniającego (Palka 2006, s. 97, 101-102, 130) pozwoliło zgromadzić dane wokół doświadczeń badanych osób, a także wyprowadzić wnioski o charakterze jakościowym dotyczące konceptualizacji wyobrażenia czarownicy oraz stosowności i wartościowania danych w odniesieniu do spodziewanej zawartości materiałów uzyskanych w badaniu (Nowakowski 2004). Takie ujęcie pozwoliło rozpatrywać stereotypowe obrazy nie tyle pod kątem ich liczby, ile znaczeń i spójności nadawanych czarownicy cech.

Badanie w grupie 17-latków miało na celu udzielenie odpowiedzi na pytania badawcze: za pomocą jakich cech badani licealiści definiują czarownicę? Jakie kategorie analityczne pojawiły się $\mathrm{w}$ tych definicjach? Czy stereotyp czarownicy przekazany w młodszych latach życia (poprzez teksty i obrazy kultury) cały czas im towarzyszy? Cele te wyznaczyły główny cel postępowania związany z kształtowaniem kompetencji wychowawczych.

Przedmiotem badań była wiedza uczniów na temat kategorii czarownicy. Badaniem objęto grupę 26 uczniów drugiej klasy licealnej, którzy zgodzili się na wypisanie swoich skojarzeń ze słowem „czarownica”. Przeprowadzono je w dwóch grupach po 13 osób (w klasie o profilu humanistycznym oraz w klasie o profilu matematyczno-informatycznym) ${ }^{3}$.

${ }^{3}$ Decyzja o przeprowadzeniu badania w klasach o dwóch różnych profilach wynikała $\mathrm{z}$ faktu, że jestem ich wychowawczynią, a udzielone odpowiedzi będą rzetelne. 
W efekcie zastosowanych badań powstał inwentarz cech, z którego w trakcie analizy treści udało się wygenerować 9 kategorii analitycznych dotyczących: fizyczności czarownicy, jej usposobienia i atrybutów, a także istot towarzyszących jej w życiu, przestrzeni i miejsca, w której żyje, umiejętności, jakie posiada, sposobów jej przemieszczania się czy wreszcie źródeł wiedzy o niej.

\section{WYNIKI BADAŃ}

Dokonana werbalizacja związana $\mathrm{z}$ definiowaniem czarownicy przez licealistów wyróżniła się bogactwem językowych określeń, wskazań, okazaniem rozmaitych wyobrażeń dotyczących badanej postaci. Z odpowiedzi badanych osób wyekscerpowano łącznie 104 werbalizacje, które można było sprowadzić do 9 głównych składników kategoryzacyjnych (tab. 1).

Tabela 1. Zestawienie zbiorcze kategorii oraz cech wyobrażeniowych czarownicy

\begin{tabular}{|c|c|c|c|c|c|}
\hline Lp. & $\begin{array}{c}\text { Nazwa } \\
\text { kategorii }\end{array}$ & $\begin{array}{l}\text { Cechy charakterystyczne/ } \\
\text { wyobrażeniowe czarownicy }\end{array}$ & $\begin{array}{c}\text { Liczba } \\
\text { wskazań: } \\
\text { klasa } \\
\text { mat.-info. }\end{array}$ & $\begin{array}{c}\text { Liczba } \\
\text { wskazań: } \\
\text { klasa } \\
\text { hum. }\end{array}$ & Razem \\
\hline 1 & \multirow{7}{*}{$\begin{array}{l}\text { Fizyczność } \\
\text { czarownicy }\end{array}$} & Krzywy nos & 3 & 5 & 8 \\
\hline 2 & & Wiek (stara) & 0 & 4 & 4 \\
\hline 3 & & Wiedźma & 3 & 1 & 4 \\
\hline 4 & & Budząca odrazę & 2 & 2 & 4 \\
\hline 5 & & Okropna (brzydka) & 1 & 2 & 3 \\
\hline 6 & & Głos z chrypą & 1 & 0 & 1 \\
\hline 7 & & Włosy/kołtuny & 0 & 1 & 1 \\
\hline 8 & \multirow{13}{*}{$\begin{array}{l}\text { Usposobienie } \\
\text { czarownicy/ } \\
\text { wartościowa- } \\
\text { nie czarownicy }\end{array}$} & Tajemnicza & 2 & 6 & 8 \\
\hline 9 & & Zla & 2 & 6 & 8 \\
\hline 10 & & Wiedza/mądra & 0 & 6 & 6 \\
\hline 11 & & Fantastyczna & 2 & 2 & 4 \\
\hline 12 & & Mistyczka/mistycyzm & 0 & 4 & 4 \\
\hline 13 & & Podstępna & 1 & 2 & 3 \\
\hline 14 & & Przebiegła & 0 & 3 & 3 \\
\hline 15 & & Sprytna & 0 & 3 & 3 \\
\hline 16 & & Demoniczna & 1 & 2 & 3 \\
\hline 17 & & Samotna & 0 & 3 & 3 \\
\hline 18 & & Chłodna & 0 & 2 & 2 \\
\hline 19 & & Ból & 0 & 2 & 2 \\
\hline 20 & & Zniszczenie/niszczycielka & 0 & 2 & 2 \\
\hline
\end{tabular}




\begin{tabular}{|c|c|c|c|c|c|}
\hline Lp. & $\begin{array}{c}\text { Nazwa } \\
\text { kategorii }\end{array}$ & $\begin{array}{l}\text { Cechy charakterystyczne/ } \\
\text { wyobrażeniowe czarownicy }\end{array}$ & $\begin{array}{c}\text { Liczba } \\
\text { wskazań: } \\
\text { klasa } \\
\text { mat.-info. }\end{array}$ & $\begin{array}{c}\text { Liczba } \\
\text { wskazań: } \\
\text { klasa } \\
\text { hum. }\end{array}$ & Razem \\
\hline 21 & \multirow{37}{*}{$\begin{array}{l}\text { Usposobienie } \\
\text { czarownicy/ } \\
\text { wartościowa- } \\
\text { nie czarownicy }\end{array}$} & Postać negatywna & 1 & 1 & 2 \\
\hline 22 & & Postrach & 0 & 2 & 2 \\
\hline 23 & & Chytra & 0 & 2 & 2 \\
\hline 24 & & Związek z mrocznymi siłami & 0 & 2 & 2 \\
\hline 25 & & Zerwanie $\mathrm{z}$ normami moralnymi & 0 & 2 & 2 \\
\hline 26 & & Śmierć & 0 & 2 & 2 \\
\hline 27 & & Podejrzana & 1 & 1 & 2 \\
\hline 28 & & Grzeszna & 0 & 2 & 2 \\
\hline 29 & & Życie zgodne $\mathrm{z}$ naturą & 0 & 2 & 2 \\
\hline 30 & & Niezależna kobieta & 0 & 2 & 2 \\
\hline 31 & & Inteligentna & 0 & 2 & 2 \\
\hline 32 & & Wyobraźnia/wytwór & 1 & 1 & 2 \\
\hline 33 & & Dobra & 0 & 1 & 1 \\
\hline 34 & & $\begin{array}{l}\text { Świadomość siebie (własnych } \\
\text { możliwości) }\end{array}$ & 0 & 1 & 1 \\
\hline 35 & & Zagadkowa & 0 & 1 & 1 \\
\hline 36 & & Dążenie do celu & 0 & 1 & 1 \\
\hline 37 & & Indywidualistka & 0 & 1 & 1 \\
\hline 38 & & Pogodna & 0 & 1 & 1 \\
\hline 39 & & Pomocna & 0 & 1 & 1 \\
\hline 40 & & Nieszablonowa & 0 & 1 & 1 \\
\hline 41 & & Pragnąca kontroli & 0 & 1 & 1 \\
\hline 42 & & Potężna & 0 & 1 & 1 \\
\hline 43 & & Podła & 1 & 0 & 1 \\
\hline 44 & & Brak logiki & 1 & 0 & 1 \\
\hline 45 & & Interesowna & 0 & 1 & 1 \\
\hline 46 & & Wredna & 1 & 0 & 1 \\
\hline 47 & & Manipulantka & 0 & 1 & 1 \\
\hline 48 & & Przyciszanie sprawy & 0 & 1 & 1 \\
\hline 49 & & Wykluczenie ze społeczeństwa & 0 & 1 & 1 \\
\hline 50 & & $\begin{array}{l}\text { Niebezpieczna/ } \\
\text { niebezpieczeństwo }\end{array}$ & 0 & 1 & 1 \\
\hline 51 & & Kanibalizm & 0 & 1 & 1 \\
\hline 52 & & Zagrożenie & 0 & 1 & 1 \\
\hline 53 & & Czarny kolor & 1 & 0 & 1 \\
\hline 54 & & Jesienna/jesień & 0 & 1 & 1 \\
\hline 55 & & Śmiała & 0 & 1 & 1 \\
\hline 56 & & Marzenia nastoletnich dziewcząt & 0 & 1 & 1 \\
\hline 57 & & Nerwowa/nerwowość & 0 & 1 & 1 \\
\hline
\end{tabular}




\begin{tabular}{|c|c|c|c|c|c|}
\hline Lp. & $\begin{array}{l}\text { Nazwa } \\
\text { kategorii }\end{array}$ & $\begin{array}{c}\text { Cechy charakterystyczne/ } \\
\text { wyobrażeniowe czarownicy }\end{array}$ & $\begin{array}{c}\text { Liczba } \\
\text { wskazań: } \\
\text { klasa } \\
\text { mat.-info. }\end{array}$ & $\begin{array}{c}\text { Liczba } \\
\text { wskazań: } \\
\text { klasa } \\
\text { hum. }\end{array}$ & Razem \\
\hline 58 & \multirow[t]{13}{*}{ Atrybuty } & Miotła & 8 & 8 & 16 \\
\hline 59 & & Mikstury/eliksiry & 5 & 4 & 9 \\
\hline 60 & & Kapelusz & 4 & 4 & 8 \\
\hline 61 & & Kocioł & 5 & 3 & 8 \\
\hline 62 & & Kula & 1 & 2 & 3 \\
\hline 63 & & Zioła/napary & 2 & 1 & 3 \\
\hline 64 & & Różdżka & 2 & 1 & 3 \\
\hline 65 & & Księga czarów/zaklęć & 2 & 1 & 3 \\
\hline 66 & & Księżyc & 1 & 0 & 1 \\
\hline 67 & & Piec & 1 & 0 & 1 \\
\hline 68 & & Ogień & 1 & 0 & 1 \\
\hline 69 & & Kamień & 0 & 1 & 1 \\
\hline 70 & & Magiczne przedmioty & 0 & 1 & 1 \\
\hline 71 & \multirow{4}{*}{$\begin{array}{l}\text { Towarzysze } \\
\text { życia }\end{array}$} & Kot & 10 & 6 & 16 \\
\hline 72 & & Ropucha & 0 & 2 & 2 \\
\hline 73 & & Mistyczne stwory & 0 & 1 & 1 \\
\hline 74 & & Myszy/szczury & 1 & 0 & 1 \\
\hline 75 & \multirow{14}{*}{$\begin{array}{l}\text { Przestrzeń } \\
\text { czarownicy } \\
\text { (miejsce, czas, } \\
\text { dom) }\end{array}$} & Sabat/wspólnota & 1 & 6 & 7 \\
\hline 76 & & Chata (piernikowa, leśna) & 4 & 2 & 6 \\
\hline 77 & & Stos & 4 & 2 & 6 \\
\hline 78 & & Ciemność & 3 & 1 & 4 \\
\hline 79 & & Las/wzgórze & 3 & 0 & 3 \\
\hline 80 & & Średniowiecze & 2 & 0 & 2 \\
\hline 81 & & Zaczarowana kraina & 1 & 0 & 1 \\
\hline 82 & & Wieża & 1 & 0 & 1 \\
\hline 83 & & Jezioro & 0 & 1 & 1 \\
\hline 84 & & Studnia & 0 & 1 & 1 \\
\hline 85 & & Bagno & 1 & 0 & 1 \\
\hline 86 & & Wybite okna & 1 & 0 & 1 \\
\hline 87 & & Kusz & 1 & 0 & 1 \\
\hline 88 & & Opary & 1 & 0 & 1 \\
\hline 89 & \multirow{9}{*}{$\begin{array}{l}\text { Umiejętności } \\
\text { czarownicy }\end{array}$} & Magia & 12 & 8 & 20 \\
\hline 90 & & Czary & 4 & 6 & 10 \\
\hline 91 & & Zaklęcia & 6 & 3 & 9 \\
\hline 92 & & Moc & 1 & 0 & 1 \\
\hline 93 & & Zjawiska nadnaturalne & 2 & 2 & 4 \\
\hline 94 & & Metafizyka & 2 & 1 & 3 \\
\hline 95 & & Iluzja & 2 & 0 & 2 \\
\hline 96 & & Zabawa & 0 & 1 & 1 \\
\hline 97 & & Znajomość przyszłości/wróżby & 0 & 1 & 1 \\
\hline
\end{tabular}




\begin{tabular}{|c|c|c|c|c|c|}
\hline Lp. & $\begin{array}{c}\text { Nazwa } \\
\text { kategorii }\end{array}$ & $\begin{array}{l}\text { Cechy charakterystyczne/ } \\
\text { wyobrażeniowe czarownicy }\end{array}$ & $\begin{array}{c}\text { Liczba } \\
\text { wskazań: } \\
\text { klasa } \\
\text { mat.-info. }\end{array}$ & $\begin{array}{c}\text { Liczba } \\
\text { wskazań: } \\
\text { klasa } \\
\text { hum. }\end{array}$ & Razem \\
\hline 98 & $\begin{array}{l}\text { Sposób prze- } \\
\text { mieszczania } \\
\text { się }\end{array}$ & Latanie & 0 & 4 & 4 \\
\hline 99 & \multirow{6}{*}{$\begin{array}{l}\text { Źródła wiedzy } \\
\text { o czarownicy }\end{array}$} & Bajki z dzieciństwa & 3 & 7 & 10 \\
\hline 100 & & Książki, np. Harry Potter & 2 & 4 & 6 \\
\hline 101 & & Halloween & 2 & 3 & 5 \\
\hline 102 & & Wierzenia ludowe & 0 & 3 & 3 \\
\hline 103 & & Horror & 2 & 0 & 2 \\
\hline 104 & & Łowcy czarownic & 1 & 0 & 1 \\
\hline
\end{tabular}

Źródło: opracowanie i badania własne.

Z badań wynika, że definicja czarownicy wpisuje się w konwencję definicji klasycznej (Wróblewska 2018, s. 368). Zasadniczo jest ujmowana jako: wiedźma, tajemnicza i zła, występująca w bajkach ludowych, w rolach fabularnych.

Uczniowie w swoich wypowiedziach wyodrębnili dwa profile czarownicy zarówno jako postaci typowo złej, jak i zaskakująco dobrej. W negatywnym wartościowaniu - czarownica okazuje się uosobieniem zła: podstępna, przebiegła, chłodna, siejąca zniszczenie, postrach, chytra, związana z mrocznymi siłami, zrywająca z normami moralnymi, powiązana ze śmiercią, podejrzana, grzeszna mająca nieczyste myśli, podła, wredna, manipulantka, uprawiająca kanibalizm, niosąca ze sobą zagrożenie, niebezpieczeństwo (47 wskazań) - zob. tab. 2.

Tabela 2. Definicja czarownicy

\begin{tabular}{|l|c|c|c|}
\hline \multicolumn{1}{|c|}{ Definicja czarownicy } & $\begin{array}{c}\text { Klasa } \\
\text { mat.- } \\
\text { info. }\end{array}$ & $\begin{array}{c}\text { Klasa } \\
\text { hum. }\end{array}$ & Razem \\
\hline $\begin{array}{l}\text { Definicja na podstawie usposobienia (negatywny): postać negatywna, zła } \\
\text { kobieta, podstępna, przebiegła, demoniczna, chłodna, niosąca ból, siejąca } \\
\text { zniszczenie, postrach, chytra, ma związek z mrocznymi siłami, zerwanie } \\
\text { z normami moralnymi, niosąca śmierć, podejrzana, grzech - mająca } \\
\text { nieczyste myśli, podła, wredna, manipulantka, interesowna, kanibalizm, } \\
\text { to zagrożenie, niosąca niebezpieczeństwo, nerwowa. }\end{array}$ & 8 & 39 & 47 \\
\hline $\begin{array}{l}\text { Definicja na podstawie usposobienia (pozytywny): tajemnicza, wiedza/ } \\
\text { mądra, fantastyczna, mistyczka, sprytna, samotna, żyje zgodne z naturą, } \\
\text { niezależna kobieta, inteligentna, dobra, świadoma siebie/własnych moż- } \\
\text { liwości, zagadkowa, dąży do celu, indywidualistka, pogodna, pomocna, } \\
\text { nieszablonowa, pragnąca kontroli, potężna, to marzenie nastolatek. }\end{array}$ & 4 & 41 \\
\hline
\end{tabular}




\begin{tabular}{|l|c|c|c|}
\hline Definicja czarownicy & $\begin{array}{c}\text { Klasa } \\
\text { mat.- } \\
\text { info. }\end{array}$ & $\begin{array}{c}\text { Klasa } \\
\text { hum. }\end{array}$ & Razem \\
\hline $\begin{array}{l}\text { Definicja przez opis wyglądu i atrybutów: krzywy nos, stara, wiedźma, } \\
\text { budząca odrazę, brzydka (okropna), włosy w kołtunach, głos ochrypnięty, } \\
\text { miotła, mikstury/eliksiry, zioła/napary, szpiczasty kapelusz, kocioł, kula, } \\
\text { różdżka, księga czarów, księżyc, piec, ogień, kamień, magiczne przedmioty. }\end{array}$ & 42 & 44 & 86 \\
\hline $\begin{array}{l}\text { Definicja przez posiadane umiejętności i atrybuty: posiada magię i moc, } \\
\text { umie czarować, rzucać zaklęcia, stosować iluzję, umie latać na miotle, } \\
\text { wróżyć (zna przyszłość), ma dar metafizyczny, umie odnaleźć się w zja- } \\
\text { wiskach nadnaturalnych, dobrze się bawić. }\end{array}$ & 29 & 26 & 55 \\
\hline $\begin{array}{l}\text { Osoba, postać zmyślona: bajki z dzieciństwa, książki np. Harry Potter, } \\
\text { Halloween, wierzenia ludowe, horror, łowcy czarownic. }\end{array}$ & 10 & 17 & 27 \\
\hline Podsumowanie & 93 & 167 & 260 \\
\hline
\end{tabular}

Źródło: badania własne.

Jej obecność w kulturze uczniowie z klasy humanistycznej postrzegają w sposób pozytywny: tajemnicza, posiadająca wiedzę/mądrość, fantastyczna w sposobie bycia, mistyczka, sprytna, samotna, prowadzi życie zgodne z naturą, niezależna, inteligentna, dobra, świadoma siebie, czyli własnych możliwości, zagadkowa, dąży do celu, indywidualistka, pogodna, pomocna, nieszablonowa, pragnąca kontroli, potężna (45 wskazań). Natomiast uczniowie z klasy matematyczno-informatycznej definiują ją stereotypowo, tzn. jest dla nich postacią tajemniczą i fantastyczną (zob. tab. 1).

Generalnie już na podstawie definicji można stwierdzić, że licealiści umieścili własne wyobrażenie czarownicy w nawiązaniu (nieświadomym) do ludowego wzorca stereotypu, polegające na rozróżnianiu dwóch profili czarownic - jako postaci dobrej i zarazem złej. Podobny wniosek z badań wyprowadziła Bernadeta Niesporek-Szamburska, posiłkując się rozpoznaniami w grupie uczniów od 11. do 13. roku życia (zob. Niesporek-Szamburska 2013, s. 154).

Niewielkie różnice w zawartości wyobrażenia baśniowego czarownicy dotyczą określania jej fizyczności - 15 wskazań nadali uczniowie z klasy humanistycznej. Natomiast 10 wskazań udzielili uczniowie klasy matematyczno-informatycznej.

Uczniowie LO sprecyzowali charakter czarownicy i jej postawę za pomocą określeń przymiotnikowych, w większości nacechowanych negatywnie (17 słów), ale też pozytywnie (14 słów). Wśród nich najczęstsze były określenia czarownicy: tajemnicza (o zabarwieniu pozytywnym - 8 wskazań) i zła (8 wskazań).

Licealiści, werbalizując lokowanie czarownicy, pokazują, że jej usytuowanie nie jest raz na zawsze określone. Kontakt z nią okazuje się bowiem możliwy w wielu miejscach (zob. tab. 3). 
Tabela 3. Przestrzeń czarownicy

\begin{tabular}{|c|c|c|c|}
\hline Miejsce czarownicy & $\begin{array}{c}\text { Klasa } \\
\text { mat.-info. }\end{array}$ & $\begin{array}{c}\text { Klasa } \\
\text { hum. }\end{array}$ & Razem \\
\hline $\begin{array}{l}\text { chata (piernikowa, leśna), sabat, stos, ciemność, las/wzgórze, średnio- } \\
\text { wiecze, zaczarowana kraina, wieża, jezioro, studnia, bagno }\end{array}$ & 20 & 12 & 32 \\
\hline
\end{tabular}

Źródło: badania własne.

To rozproszenie świadczy zarówno o wielowątkowości wyobrażenia, jak i o scalaniu (stapianiu) (Libura 2007, s. 11-66), w jego obrazie komponentów należących do różnych prototypów: czarownica i wiedźma, przebywały w różnych miejscach, z dala od ludzi, baba-jaga - w lesie (Niesporek-Szamburska 2013, s. 165).

Badani najczęściej wymieniali chatkę w lesie, należącą do terenów odosobnionych, zaciemnionych, zaczarowanych, powiązanych z magią. Ponad $46 \%$ badanych uczniów z klasy humanistycznej wyraźnie nawiązało do sabatu jako miejsca lokatywności czarownicy.

W badaniu dotyczącym działań czarownicy wyniki są zbliżone do prac podjętych przez Bernadetę Niesporek-Szamburską, lecz przeprowadzonych w młodszej grupie wiekowej (10-13 lat) (Niesporek-Szamburska 2013, s. 175), gdzie czołowe miejsce w wyobraźni uczniowskiej zajmują czary i magia (30 wskazań) oraz zaklęcia (9 wskazań). W jednostkowych ujęciach uczniowie wymieniają czynności typowe dla prototypu wróżki (znajomość przyszłości).

Z kolei źródła wiedzy o czarownicy w znaczącej formie występują w bajkach i baśniach $z$ dzieciństwa, w literaturze, zwyczaju i tradycji, np. Halloween, w wierzeniach ludowych, filmach fabularnych (zob. tab. 1, poz. 99-103).

\section{DYSKUSJA WYNIKAJĄCA Z WYNIKÓW I WNIOSKI}

Pojęcie czarownicy w wypowiedziach młodych ludzi jest rozumiane dwojako, wyobrażają ją sobie zarazem jako dobrą, jak i złą, to postać stereotypowa z dominacją magii, obecnością czarnego kota i miotły jako atrybutu, dzięki któremu przemieszcza się. W tym stereotypowym obrazie czarownicy ustabilizowały się cechy kryterialne, językowe (jak bycie kobietą oraz czarowanie), a także ujawniło się wiele cech bogatych w znaczenie np. konotacyjne, potwierdzające dane wierzeniowe (jak specyficzne zachowania, miejsca, odmienność, samotność).

Porównanie stereotypowych obrazów czarownicy w obu klasach o odmiennych profilach edukacyjnych pozwoliło zauważyć, że znany nam stereotyp kulturowo-językowy jest podobnie werbalizowany przez wszystkich uczestników, lecz wraz $\mathrm{z}$ wiekiem są dostrzegalne również cechy nietypowe dla stereotypu (za: Niesporek- 
-Szamburska 2013, s. 181). Szczególnie zauważa się to wśród uczniów klasy humanistycznej, których język jest bogaty, a myślenie dywergencyjne. Podczas określania jednej z kategorii - usposobienia czarownicy (wymieniono 50 jej cech) - okazało się, że jest ona różnie wartościowana: uczniowie klasy humanistycznej podali 37 zupełnie innych skojarzeń niż uczniowie z klasy matematyczno-informatycznej. Identyczne wskazywane przez obie grupy wartości okazały się znikome (5 wskazań: tajemnicza, fantastyczna, zła, podejrzana, wytwór wyobraźni). Zatem zaobserwowano, że uczniowie z klasy humanistycznej dokonują zmiany w myśleniu stereotypowym. A postać czarownicy - wyemancypowanej kobiety, zgodnie z teorią blednięcia stereotypu, wraz z wiekiem przejawia mniej stereotypową percepcję (Weigl 1999). W badaniu okazało się więc, że wraz z rozwojem jednostkowej dojrzałości i zarazem intensywnością edukacji humanistycznej można mówić o przejawach transformacji - powstaje nowy człowiek, który nie ulega, ale przekształca świat i myśli w skali całego globu - jak ujął to Czesław Miłosz.

W literaturze - postać czarownicy - jest ucieleśnieniem kobiety wolnej od wszelkiej dominacji, od wszelkich ograniczeń, bezustannie doskonalącej się, poświęcającej się życiu i jego ochronie, wskazującej drogę, pozwalającej na przeobrażenia dziewczynki w kobietę, dziecka w dorosłego; takie postrzeganie bohaterki pozwala na odrodzenie się jej w nowej postaci (zob. Bettelheim 1989, Eliade 1997). Wiele przekazów bajkowych towarzyszy ludziom przez całe życie. A ukazane w nich czarownice kształtują m.in. ich poczucie przynależności (do danego kręgu kulturowego), budzenie ich świadomości (w sensie odpowiedzialności), tożsamości, samodzielności, zrozumienia.

Dorota Wojciechowska podkreśla, że:

w miarę upływu czasu nasza zdolność formowania i manipulowania symbolami wzrasta i te same postacie czy zdarzenia z zapamiętanych w dzieciństwie bajek stymulują naszą wyobraźnię na innych, bardziej zaawansowanych poziomach samopoznania i rozwoju (Wojciechowska 2003, s. 306).

W badaniach widoczne jest również to, że czarownica kryje w sobie prawdziwą duszę kobiety z jej tajemniczością, mądrością, mistycyzmem, sprytem i niezależnością. „Niezależnie od okoliczności życia, człowiek pozostaje duchową osobą, w której odciśnięty jest boży obraz" (Kostyło 2019, s. 592). Trzeba o tym pamiętać, szczególnie wówczas gdy mamy do czynienia z ludźmi wykluczonymi, zmarginalizowanymi czy egzystującymi w ubóstwie lub poniżeniu. Obraz ten doskonale wpisuje się w założenia pedagogiki emancypacyjnej, która dąży do stworzenia takich warunków, w których stosunki między jednostkami wynikają z zasady komunikacji i niewymuszonego konsensusu, nie zaś z zasady panowania 
(Kostyło 2019, s. 588). Kobieta-czarownica eksponuje naczelny cel wychowania, jakim jest bycie „wolną osobowością” kształtowaną przez całe życie w toku socjalizacji, edukacji, inkulturacji oraz uczłowieczenia ${ }^{4}$, jest wyzwolona, oswobodzona, usamodzielniona i niezależna.

Konkludując, powyższe rozważania są jedynie inspiracją do dalszych badań. Bowiem refleksja nad personifikacjami dobra i umiejętność jego rozpoznawania w postaci często marginalnej, naznaczonej historycznie, może być narzędziem kształtowania kompetencji wychowawczych wspierających indywidualny rozwój człowieka z jego bagażem doświadczeń, potencjałem rozwojowym, uczeniem szacunku do drugiej osoby i jej prawa do kształtowania indywidualności, autonomii i uczeniem akceptacji jego wolnych wyborów.

\section{LITERATURA}

Bechtel G., 2015, Cztery kobiety Boga: ladacznica, czarownica, święta, głupia geśs. Warszawa, Wydawnictwo Akademickie Dialog.

Bettelheim B., 1989, Rany symboliczne. Rytuały inicjacji i zazdrość męska. Warszawa, Wydawnictwo Czytelnik.

Bolińska M., 2008, Właściwości ludyczne opowiadań i bajek terapeutycznych (na wybranych przykładach). „Napis”, seria XIV.

Briggs R., 1998, Witches and Neighbors. New York, Penguin Books.

Cawihorne N., 2006, Wiedźmy i czarownice. Historia prześladowań. Warszawa, Bellona. Chollet M., 2019, Czarownice. Niezwyciężona siła kobiet. Kraków, Wydawnictwo Karakter.

Czerepaniak-Walczak M., 2003, Pułapki izonomii rozwojowej w baśniowym świecie (o potrzebie krytycznej refleksji nad bajkami jako środkiem wychowawczym). W: U. Chęcińska (red.), Barwy świata baśni. Szczecin, Wydawnictwo Naukowe Uniwersytetu Szczecińskiego.

Czerepaniak-Walczak M., 2006, Pedagogika emancypacyjna. Rozwój świadomości krytycznej człowieka. Gdańsk, Gdańskie Wydawnictwo Psychologiczne.

Eliade M., 1997, Inicjacja, obrzędy, stowarzyszenia tajemne (Narodziny mistyczne). Kraków, Wydawnictwo Znak.

Frankfort-Nachmias C., Nachmias D., 2001, Metody badawcze w naukach społecznych. Poznań, Wydawnictwo Zysk i S-ka.

${ }^{4}$ O procesach wpływających na rozwój, wychowanie czy zmiany osobowości pisał Zbigniew Kwieciński (1995) w tekście Dziesięciościan edukacji (składniki i aspekty - potrzeba całościowego ujęcia). W: Z. Kwieciński, Socjopatologia edukacji. Olecko, Mazurska Wszechnica Nauczycielska, 13-20. Z nazwiskiem autora wiąże się rozwój pedagogiki emancypacyjnej w Polsce. 
Girard R., 1991, Kozioł ofiarny. Łódź, Wydawnictwo Łódzkie.

Gripe M., 1983, Dzieci szklarza. Warszawa, Instytut Wydawniczy „Nasza Księgarnia”. Koczanowicz-Dehnel I., 2011, Hermeneutyka a narracja. „Teraźniejszość, Człowiek, Edukacja”, nr 3 (55), 33.

Kostyło H., 2019, Pedagogika emancypacyjna. W: Z. Kwieciński, B. Śliwerski (red.), Pedagogika. Podręcznik akademicki. Warszawa, Wydawnictwo Naukowe PWN.

Kwieciński Z., 1995, Dziesięciościan edukacji (składniki i aspekty-potrzeba całościowego ujęcia). W: Z. Kwieciński, Socjopatologia edukacji. Olecko, Mazurska Wszechnica Nauczycielska, 13-20.

Levack P., 2009, Polowanie na czarownice w Europie wczesno nowożytnej. Wrocław, Ossolineum.

Michelet J., 1961, Czarownica. Warszawa, Wydawnictwo Czytelnik.

Miłosz C., 1953, Zniewolony umysł. Paryż, Instytut Literacki: Libella.

Molicka M., 1999, Bajki terapeutyczne. Poznań, Media Rodzina.

Niesporek-Szamburska B., 2013, Stereotyp czarownicy i jego modyfikowanie. Katowice, Wydawnictwo Uniwersytetu Śląskiego.

Nowakowski P.T., 2004, Modele człowieka propagowane w wybranych czasopismach młodzieżowych. Analiza antropologiczno-etyczna. Tychy, Maternus Media.

Olek-Redlarska Z., 2015, Rozumienie pojęć moralnych w wychowaniu moralnym dzieci młodszych. Empatia i motywacja do zachowań moralnych. „Rocznik Teologii Katolickiej”, t. XIV/2.

Palka S., 2006, Metodologia badania. Praktyka pedagogiczna. Gdańsk, Gdańskie Wydawnictwo Psychologiczne.

Pilaszek M., 2008, Procesy o czary w Polsce w wiekach XV-XVIII. Kraków, Universitas. Procesy czarownic w Rzeczypospolitej Obojga Narodów, opublikowano: https://www. rp.pl/Rzecz-o-historii/310149995 [dostęp: 7.11.2019].

Propp W., 2000, Nie tylko bajka, Warszawa, Wydawnictwo Naukowe PWN.

Rella A., 2003, Czy to tylko bajka? Czyli perswazja poprzez bajkę. W: U. Chęcińska (red.), Barwy świata baśni. Szczecin, Wydawnictwo Naukowe Uniwersytetu Szczecińskiego. Rzepa T., 2003, Po co potrzebny nam diabeł? W: U. Chęcińska (red.), Barwy świata baśni. Szczecin, Wydawnictwo Naukowe Uniwersytetu Szczecińskiego.

Sallmann J.M., 1994, Czarownice. Oblubienice szatana. Wrocław, Wydawnictwo Dolnośląskie.

Słownik polskiej bajki ludowej, Tom 1 a-c, 2018, V. Wróblewska (red.), Toruń, Wydawnictwo Naukowe Uniwersytetu Mikołaja Kopernika.

Smogorzewska J., Rozpoznawanie twórczości werbalnej dziecka w wieku przedszkolnym - problemy i rozwiąania. W: M. Karwowski (red.), Identyfikacja potencjału twórczego. Teoria, metodologia, diagnostyka. Warszawa, Akademia Pedagogiki Specjalnej. 
Stark R., 2018, Nie mów fałszywego świadectwa. Odkłamywanie wieków antykatolickiej narracji. Warszawa, Państwowy Instytut Wydawniczy.

Symonowicz-Jabłońska I., 2018, Czarownica w ujęciu pedagogiki emancypacyjnej - na przykładzie analizy literatury dziecięcej. W: I. Glatzel (red.), Jak dorobić się skrzydet? 20-lecie Zespołu Szkół Uniwersytetu Mikołaja Kopernika Gimnazjum i Liceum Akademickiego $w$ Toruniu. Toruń, ZS UMK Gimnazjum i Liceum Akademickie. Śliwerski B., 2015, Współczesne teorie i nurty wychowania. Kraków, Oficyna Wydawnicza Impuls.

Weigl B., 1999, Stereotypy i uprzedzenia etniczne u dzieci i młodzieży. Warszawa, Wydawnictwo Instytutu Psychologii PAN.

Wojciechowska D., 2003, Psychoterapeutyczne znaczenie baśni. W: U. Chęcińska (red.), Barwy świata baśni. Szczecin, Wydawnictwo Naukowe Uniwersytetu Szczecińskiego.

\title{
EDUCATIONAL IMPLICATIONS OF A WITCH CHARACTER - AN EXTRAORDINARY WOMAN IN THE CONTEXT OF EMANCIPATORY PEDAGOGY
}

\begin{abstract}
Contemplations on a woman-witch inscribed in the foundations of emancipatory pedagogy is to show modification of her current image, open up a new research opportunity that allows for a broader view of the witch as an interpreter of culture that does not fit into the main centralist trend of thinking about the world. So does the woman witch In basic mental stereotypical human constructions seen as a destructive and malicious figure, always represent the opposite of all positive values, or can she be perceived as a positive character ? Or maybe [does she] "work in two ways: while being a myth she is both true and illusion" (Rella 2003, p. 295)? Does the image of a witch change because of adolescence? The article presents the results of the research carried out among the youth of the secondary school in Torun. Thanks to the used focus method a catalogue of features defining the witch was created. The study involved 26 people (13 from the humanities class and 13 from the mathematics and IT class) and aimed at identifying differences in terms of verbalized values between the two groups.
\end{abstract}

Keywords: witch, emancipation pedagogy, fable/fairy tale 